\title{
Growth Parameters Evaluation and Identification of Growth Hormone Receptor Gene Polymorphisms in Various Strains of Rainbow Trout Oncorhynchus mykiss
}

Abdolvahab Ebrahimpour Gorji*, Hossein Rahmani and Ghodrat Rahimi Miyanji

Department of Fisheries, Faculty of Animal Sciences and Fisheries, Sari Agricultural and Natural Resources University, Iran

\begin{abstract}
In the present study, polymerase chain reaction-single strand conformation polymorphism (PCR-SSCP) and restriction fragment length polymorphism (RFLP) methods were compared to analyze the polymorphism of growth hormone receptor (GHR) gene in French, Iranian and Danish strains of Oncorhynchus mykiss. A monomorphic SSCP pattern of AA genotype in the French and Iranian strains and a dimorphic AA and AB genotype in the Danish strain were observed in 3' non-coding regions of GHR gene. In the Danish strain, the AB genotype polymorphism of the GHR gene with its very low frequency $(5 \%)$ has no effect on the production trait. While, RFLP-Dde1 showed no polymorphism with genetic variation in the location of GHR. Moreover, comparing the condition factors $(\mathrm{K})$ of three different rainbow trout strains showed a significant correlation between the French $(1.312 \pm 0.13)$, Iranian $(1.245 \pm 0.17)$ and Danish strains $(0.763 \pm 0.1)$, respectively $(p<0.05)$. In particular, the French strain obtained a higher $\mathrm{K}$ compared to the two others. The length-weight relationship is shown by the following equations $\mathrm{W}=0.013$ $\times L^{2.921}, W=0.012 \times L^{3.023}$ and $W=0.007 \times L^{3.176}$ for French, Iranian and Danish strains, respectively. With the mean $(b=2.921)$, the studied French strain exhibited a negative allometric growth $b<3$ while the Iranian $(b=3.023)$ and the Danish $(b=3.176)$ showed positive allometric growths. Regardless of the underlying mechanism(s) responsible for the different relationships, the results of this study suggested that the $A A$ and $A B$ genotypes polymorphism of the GHR gene are not associated with condition factor and environmental variables can influence condition factor and length-weight relationship of rainbow trout strains in this study.
\end{abstract}

Keywords: Growth hormone receptor; Enzyme digestion; Single strand conformation polymorphism; Rainbow trout; Length-weight

\section{Introduction}

Hormones, growth factors, and other regulatory proteins associated with the so-called "somatotropicaxis" arecandidatemarkers for quantitative trait in farm animals [1]. The biological effect of growth hormone (GH) plays numerous important and central physiological roles in the growth, metabolism, reproduction, immune function, osmoregulation, and other physiological functions of fish and other vertebrates [2,3]. Growth hormone receptor (GHR) is the cell surface receptor for $\mathrm{GH}$ and is required for GH to carry out its effects on target tissues [4]. As a receptor, GHR mediates the biological actions of GH on target cells by transducing the GH stimulating signal across the cell membrane and subsequently inducing the transcription of many genes, including IGF-I [5]. Although there are few studies on GHR in fish, in Atlantic salmon GHR appears to play a similar role within the somatotropic axis as in humans and its differential expression is what mediates the cellular response to $\mathrm{GH}$ plasma levels, and in particular the production of IGF [6].

The fish GHR gene has been successfully cloned and characterized in several fish species such as gilthead sea bream (Sparus aurata) [7], Atlantic (Salmo salar) and masu salmon (Oncorhynchus masou) [8], and rainbow trout (Onchorhynchus mykiss) [9]. Significant associations have been observed between GHR gene polymorphism and growth rates by PCR restriction fragment polymorphism (RFLP) marker (using four restriction enzymes) in 353 individual Cyprinus carpio fish [10].

Accordingly, cost and time can be significantly reduced based on restriction analysis particularly when a large number of restriction enzyme needed. Additional gene segments can then be included in the analysis favored of population genetic studies and identification of species based on Single-Stranded Conformation Polymorphism (SSCP) analysis. The disadvantage of RFLP method is that mutations are recognized only when they occur in the sequence recognized by the restriction endonuclease, and that PCR products may need to be tested with many different restriction enzymes $[11,12]$. Because of this limitation, the SSCP technique is more appropriate for detecting point mutations and is more useful than PCR-RFLP to detect polymorphism [12].

In so far as our knowledge is concerned, no prevalent polymorphic site at this locus has been identified. However, given the significant associations between polymorphisms and growth modulation in other vertebrates, this gene should be further examined as a possible candidate for the enhancement of production in finfish. Therefore, the goal of this study is to compare morphometric parameters determine the employment of PCR-RFLP and SSCP methods, and find out whether or not the polymorphism in the 3'-UTR of the GHR gene can affect the condition factor $(\mathrm{K})$ in the aforementioned strains (French, Iranian, and Danish) of rainbow trout.

\section{Materials and Methods}

\section{DNA extraction}

One hundred twenty rainbow trout of French, Iranian and Danish strains were collected from different rainbow trout breeding farms in

*Corresponding author: Abdolvahab Ebrahimpour Gorji, Department of Fisheries, Faculty of Animal Sciences and Fisheries, Sari Agricultural and Natural Resources University, Km 9 Darya Boulvard, P.O. Box: 578, Sari, Iran, Tel: 0098-151-38227; E-mail: av.ebrahimpour@yahoo.com

Received May 26, 2016; Accepted July 27, 2016; Published July 29, 2016

Citation: Gorji AE, Rahmani H, Miyanji GR (2016) Growth Parameters Evaluation and Identification of Growth Hormone Receptor Gene Polymorphisms in Various Strains of Rainbow Trout Oncorhynchus mykiss. J Aquac Res Development 7: 435 doi:10.4172/2155-9546.1000435

Copyright: $\odot 2016$ Gorji AE, et al. This is an open-access article distributed unde the terms of the Creative Commons Attribution License, which permits unrestricted use, distribution, and reproduction in any medium, provided the original author and source are credited. 
Citation: Gorji AE, Rahmani H, Miyanji GR (2016) Growth Parameters Evaluation and Identification of Growth Hormone Receptor Gene Polymorphisms in Various Strains of Rainbow Trout Oncorhynchus mykiss. J Aquac Res Development 7: 435. doi:10.4172/2155-9546.1000435

Page 2 of 5

Mazandaran province (40 samples per strain). In order to isolate the DNA and assay RFLP and SSCP, fin clips were cut from the fish and placed in phenol chloroform and $1 \mathrm{ml}$ ethanol based on Sambrook et al. [13]. The fin clip tissue samples were transferred to the laboratory in dry ice and stored at a temperature $-20^{\circ} \mathrm{C}$ until used for the assay. The DNA was extracted using phenol-chloroform method and the quality and concentration of DNA were assessed through the use of $1 \%$ agarose gel electrophoreses. The extracted DNA samples were then stored at $-20^{\circ} \mathrm{C}$ until used for RFLP and SSCP assay.

\section{Primer design and PCR amplification}

The ethanol-precipitated DNA sample extracted from each individual fish was used as a template in SSCP and RFLP procedures. The oligonucleotide primers were designed with Primer 5 plus software [14] using information from a Genbank accession number (EU084720.1) on genomic GHR gene sequences of rainbow trout.

Forward and reverse primer sequences were: 5'TAAATGCCATCACAAGGA-3' and 5'-AAAGCCACAGTCAATCAG-3', respectively. This pair of primer is expected to amplify a $188 \mathrm{bp}$ segment of the GHR gene, encompassing the sequence from 3'UTR. The optimized PCR reaction mix was performed in a $25 \mathrm{ml}$ containing $10 \mathrm{mM}$ of Tris- $\mathrm{HCl}$ with a $8.3 \mathrm{pH}, 50 \mathrm{mM}$ of $\mathrm{KCl}, 2.3 \mathrm{mM}$ of $\mathrm{MgCl}_{2}, 0.01 \%$ gelatin, 100 $\mathrm{mM}$ of dATP, dCTP, dGTP and dTTP, $0.2 \mathrm{mM}$ of each primer, 5-50 ng of genomic DNA template, and 0.625 unit of Taq DNA polymerase. Amplification of the GHR gene by PCR was done on a thermocycler (BIORAD) with an initial denaturation of $5 \mathrm{~min}$ at $95^{\circ} \mathrm{C}$ where it was processed through 35 cycles consisting of $30 \mathrm{~s}$ at $95^{\circ} \mathrm{C}, 30 \mathrm{~s}$ at $60^{\circ} \mathrm{C}$ and $20 \mathrm{~s}$ at $72^{\circ} \mathrm{C}$ with the last elongation step lengthened to $10 \mathrm{~min}$ at $72^{\circ} \mathrm{C}$.

\section{SSCP and RFLP}

As in described below the DNA of each sample was amplified by PCR and analyzed by SSCP. Aliquots of $5 \mu \mathrm{l}$ of the above mentioned PCR products were mixed with $5 \mu \mathrm{l}$ of the denaturing ( $95 \%$ formamide, $25 \mathrm{~mm}$ of EDTA, $0.025 \%$ xylenecyanole and $0.025 \%$ bromophenolblue), heated for $10 \mathrm{~min}$ at $95^{\circ} \mathrm{C}$ and chilled immediately on ice. Denatured DNA ran in a $1 \mathrm{x}$ TBE buffer (containing $89 \mathrm{mM}$ of Tris-Borate, and 2 $\mathrm{mM}$ of EDTA, with a $8.3 \mathrm{PH}$ ) for $20 \mathrm{~h}$ at $4^{\circ} \mathrm{C}$ under a constant voltage $(150 \mathrm{~V})$ with $14 \%$ polyacrylamide gel. The gel was stained with $0.1 \%$ silver nitrate and was visualized with $2 \% \mathrm{NaOH}$ solution (containing $0.1 \%$ formaldehyde) according to Zhang et al. $[15,16]$.

For RFLP analysis, $7 \mu \mathrm{l}$ of the PCR products were digested by 4 units of Dde1 restriction enzyme and were incubated at $37^{\circ} \mathrm{C}$ for $4-12$ h. Digested DNA fragments were separated using electrophoresis employing $2 \%$ agarose gel in $1 \mathrm{x}$ TBE (containing $89 \mathrm{mM}$ of Tris-Borate, and $2 \mathrm{mM}$ of EDTA). The gel was stained with ethedium bromide and was visualized under UV light.

\section{Length-weight relationship and condition factor}

The exact relationship between length and weight differs among species of fish according to the inherited body shape for some species, and the condition (robustness) of the individual fish for others [17]. The relationship between the length (L) and weight (W) of fish is expressed by the following equation [18]:

\section{$\mathrm{W}=\mathrm{aL}^{\mathrm{b}}$}

Where (a) and (b) are the parameters of the above nonlinear model with the latter being a numeral between 2 and 4 . Taking logarithmic transformation on both sides of the above equation and the linearized model can be obtained:

\section{$\log \mathrm{W}=\mathrm{b} \log \mathrm{L}+\log \mathrm{a}$}

The correlation coefficient $\mathrm{r}^{2}$, i.e., the degree of association between the length and weight was computed through the linear regression analysis:

\section{$\mathrm{R}=\mathrm{r}^{2}$}

Confidence intervals were calculated for b slops to see if these were statistically different from 3 (allometric ranges more than 3 show positive allometry while $\mathrm{b}<3$ indicates negative allometry) or were equal with 3 ( $b=3$ shown an isometric range). Growth pattern was estimated using Pauly's modified t-test (1983).

$$
t=S d \operatorname{LnL} / S d \operatorname{Ln} W \times|b-3| / \sqrt{1-r^{2}} \times \sqrt{n-2}
$$

The condition factor $(\mathrm{K})$ of the experimental fish was estimated from the relationship [18]:

$$
K=W \times 100 / L^{b}
$$

The study of condition, a standard practice in fisheries ecology, is based on the analysis of length-weight data and assumes that heavier fish of a given length are in better conditions [19]. The $\mathrm{K}$ of fish is influenced by the reproductive organs stage of development [20] therefore, when comparing $\mathrm{K}$, it is important to sample the populations at the same time of the year when the populations are at the same stage of the reproductive cycle [21].

\section{Statistical analyses}

Genotype frequencies were determined for each strain by direct counting. For the association studies, the trait of interest was analyzed using the General Linear Model (GLM) procedure of the SAS program (SAS Institute Inc, Version 9.1 edition). Moreover regression and Correlation analysis (RECA) for linear regression of length and weight of fish were done with Microsoft Excel (2010), One-way ANOVA was used to determine the effects of strains on K using SPSS (version 17). Duncan's multiple range tests were then used to compare differences between the means at $5 \%$ probability.

\section{Results}

Based on the sequences of the rainbow trout GHR gene available in the GenBank, a pair of PCR primers amplifying the 3'UTR region was designed. Using them, 188 bp of GHR was amplified from nucleotide 285 to nucleotide 473 through the use of PCR-SSCP method (Figure 1).

Monomorphic AA genotype was observed in French and Iranian strains while $\mathrm{AB}$ pattern was observed in the Danish strain and the AA genotype was almost fixed in the all strains. On the other hand, RFLPDdel showed no polymorphism with genetic variation in the location of GHR (Table 1).

Through SSCP method, the AB genotype of the Danish strain was presented at $5 \%$. The mean values \pm SD of the investigated trait and the effects of GHR genotypes are shown in (Table 2).

The length-weight (L-W) relationship equation 1-3, growth pattern and $\mathrm{K}$ (condition factor) model were fitted to the dataset. There was a strong variation in the $\mathrm{K}$ among French, Iranian and Danish rainbow trout strains. The K varied between 1.079 and 1.629 of the French, 0.680 and 1.584 for the Iranian and 0.514 and 0.954 for the Danish trains. K value in all three strains were presented in Table 3 and demonstrated that $\mathrm{K}$ in the three strains were significantly different $(\mathrm{p}<0.05)$.

The following equations were detected for each strain (Figure 2): 


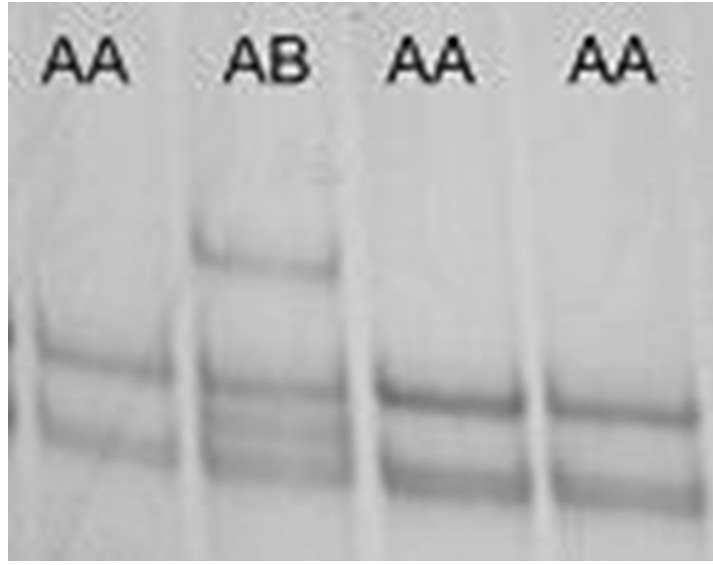

Figure 1: PCR-SSCP banding pattern of GHR in a $14 \%$ non-denaturing polyacryl-amide gel.

\begin{tabular}{|c|c|c|c|c|c|}
\hline \multirow{3}{*}{ Methods } & \multirow{3}{*}{ Strains } & \multicolumn{2}{|c|}{ Genotype } & \multicolumn{2}{c|}{ Allele } \\
\cline { 3 - 6 } & & AA & AB & A & B \\
\hline \multirow{4}{*}{ SSCP } & & & & & \\
\cline { 2 - 6 } & French & 100 & - & 100 & - \\
\cline { 2 - 6 } & Iranian & 100 & - & 100 & - \\
\cline { 2 - 6 } & Danish & 95 & 5 & 97.5 & 2.5 \\
\hline \multirow{3}{*}{ RFLP } & & & & $(-)$ & $(+)$ \\
\cline { 2 - 6 } & French & 100 & - & 100 & - \\
\cline { 2 - 6 } & Iranian & 100 & - & 100 & - \\
\cline { 2 - 6 } & Danish & 100 & - & 100 & - \\
\hline
\end{tabular}

Table 1: Frequency of alleles and genotypes of GHR gene (\%) with SSCP and RFLP analysis.

\begin{tabular}{|c|c|}
\hline Genotype & K \\
\hline AA & $1.3501 \pm 0.02$ \\
\hline AB & $1.2907 \pm 0.12$ \\
\hline
\end{tabular}

Table 2: Means \pm SD for $K$ trait based on genotypes of Danish strain in rainbow trout.

(1) Frenchstrains: $W=0.013 \times L^{2.921} R^{2}=0.856$

(2) Iranian strains: $W=0.012 \times L^{3.023} R^{2}=0.920$

(3) Dunish strains: $W=0.007 \times L^{3.176} R^{2}=0.877$

\section{Discussion}

In this study, the effect of GHR gene polymorphism and its association with production trait in the various strains of rainbow trout were analyzed. Monomorphic SSCP patterns of AA genotype in two French and Iranian strains and a dimorphic $\mathrm{AA}$ and $\mathrm{AB}$ genotype in the Danish strain were observed. Our data showed that in the latter strain, the $\mathrm{AB}$ genotype polymorphism of the GHR gene was of a very low frequency (5\%) and not associated with K. Furthermore, the RFLP and SSCP markers were compared in order to detect and identify the polymorphism of the GHR gene. According to the data gathered through SSCP marker, RFLP could detect any polymorphism in the GHR 3'-UTR. Clearly, when dealing with short PCR fragments (188 bp in our case), cutting small PCR fragment with restriction enzymes decline, and long PCR fragments can increase the chance to detect polymorphisms as was demonstrated for GHR gene by RFLP. in this study and analyzed by SSCP is higher than the limit up that reported previously and considered to be exhaustive which is about $150-200$ bp [22]. Advantages of SSCP analysis over RFLP analysis have been emphasized previously [23]. SSCP analysis can be done through the use of low level of PCR mixture and a single SSCP gel, which in the long run turned out to be a much more economic method [24]. Another advantage of SSCP analysis is that multiple polymorphism scan be easily identified by re-amplifying and directly sequencing each distinctive band on the gel without the need for long cloning procedures.

$\mathrm{K}$ is often associated with fitness, a bad condition for the individual fish. Reproductive success can be reduced through low fecundity, reduction in egg quality or low sperm quality [25] and [26]. Inappropriate conditions may also lower the chances of survival [27]. However, the results of this study showed the diversity of GHR gene in the Danish strain. Shaki et al. [28] reported the genetic distance in three different rainbow strains at $0.0008,0.1976$ and 0.1988 among IranianFrench, Iranian- Danish and French-Danish strains, respectively. According to this result, when $\mathrm{K}$ is an appropriate estimate of fitness in rainbow trout strains, our results are in agreement with population genetics theory, which predicts that higher genetic variability increases mean fitness of strains [29]. It should be noted that $\mathrm{K}$ in the French strain was higher than in the other two strains. The differences in weight for all strains maybe due to the individual $\mathrm{K}$ as it is related to the well-being and degree of fatness [18]. Our data showed that the farm condition of the Danish strain maybe almost unfavorable in comparison to the other strains. However, compared with the current study, the K values of the French and Iranian rainbow trout are relatively higher than those reported previously. Shah et al. [30] reported that the value of $\mathrm{K}$ ranged from 0.95 to 1.44 (average $K=1.15 \pm 0.111$ ) for Oncorhynchus mykiss Walbaum which is close to unity, indicating that the fish are in excellent conditions. Moreover, Rabe et al. [31] found the value of $\mathrm{K}$ to be between 0.859 and 1.104 for rainbow trout in Alpine lakes and Cada et al. [32] reported condition factors for rainbow trout collected from southern Appalachian streams that ranged from 0.82 to 1.17.

The results L-W regressions are useful for [17]:

- Calculating the total weight of fish taken from the lengthfrequency data.

Table 3: Mean \pm S.D of $L-W$ relationship and $K$ in rainbow trout.

\begin{tabular}{|c|c|}
\hline Strains & $\mathrm{K}$ \\
\hline French & $1.312 \pm 0.13^{\mathrm{a}}$ \\
\hline Iranian & $1.245 \pm 0.17^{\mathrm{b}}$ \\
\hline Danish & $0.763 \pm 0.1^{\mathrm{c}}$ \\
\hline
\end{tabular}

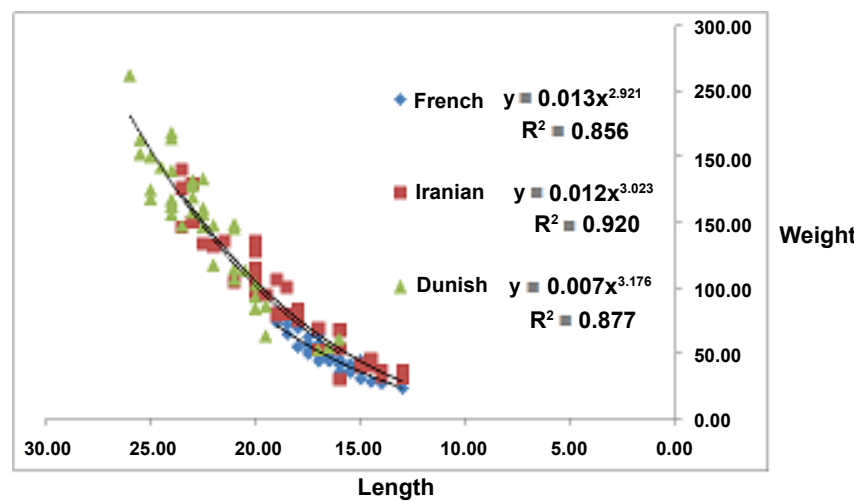

Figure 2: Length-weight relationships of French, Iranian and Danish strains. 
Citation: Gorji AE, Rahmani H, Miyanji GR (2016) Growth Parameters Evaluation and Identification of Growth Hormone Receptor Gene Polymorphisms in Various Strains of Rainbow Trout Oncorhynchus mykiss. J Aquac Res Development 7: 435. doi:10.4172/2155-9546.1000435

- Measuring changes in robustness and health of this population.

- $\quad$ Pacifying the relative condition of small fish compared to large fish.

- Comparing the condition of this population to the state-wide standards discussed below.

The length exponent of 2.921, 3.023 and 3.176 for French, Iranian and Danish strains, respectively, showed isometric growth and our results are in agreement with the Shah et al. [30] and Ekeng [33]. However, the $\mathrm{b}$ association was the $0.714,0.381$ and 0.537 for FrenchIranian, French-Danish and the Iranian-Danish, respectively, and showed no statistically significant relationship ( $p>0.05$ ). The $b$ value in the L-W relationship of fish can be used as an indicator of food intake and growth pattern, and may differ according to biotic and abiotic factors such as water temperature, food availability and habitat type [34].

In the beginning of this study, only one rainbow trout GHR gene sequence (accession no. EU084720.1) was available in the GenBank. To our knowledge, this is the first study to investigate, compare and determine whether the polymorphism in the 3'-UTR of the GHR gene is related to K using PCR-RFLP and SSCP methods. In the course of this study, we were not able to sufficiently investigate the relationship between genotype and $\mathrm{K}$ on the individual level. It may be due to the limited number of loci and individuals per strains in any cases, between strains, no correlation was found between the genotypes (using SSCP marker) and the $\mathrm{K}$ in the Danish strain.

\section{Conclusion}

In summary, $\mathrm{K}$ is an appropriate estimate of fitness in rainbow trout strains. Our results suggest that in strain Danish, the AB genotype polymorphism of the GHR gene were not associated with the $\mathrm{K}$ of rainbow trout. Furthermore, environmental conditions are evidently important in determining the $\mathrm{K}$ of rainbow trout strains. Emphasizing the importance of performing similar studies in different parts of the distribution range of a species, to get an impartial idea of the generality and importance of the relationship of interest. More studies are needed, and attention to positive as well as neutral results will allow for the explanation of possible patterns and processes.

\section{References}

1. Parmentier I, Portetelle D, Gengler N, Prandi A, Bertozzi C, et al. (1999) Candidate gene markers associated with somatotropic axis and milk selection. Domestic Animal Endocrinology 17: 139-148.

2. Bjornsson BT (1997) The biology of salmon growth hormone: from daylight to dominance. Fish Physiology and Biochemistry 17: 9-24.

3. Bjornsson BT, Johansson V, Benedet S, Einarsdottir IE, Hildahl J, et al. (2002) Growth hormone endocrinology of salmonids: regulatory mechanisms and mode of action. Fish Physiology and Biochemistry 27: 227-242.

4. Moody D, Pomp D, Barendse W, Womack J (1995) Assignment of the growth hormone receptor gene to bovine chromosome 20 using linkage analysis and somatic cell mapping. Animal Genetics 26: 341-343.

5. Kobayashi Y, Vandehaar M, Tucker H, Sharma B, Lucy M (1999) Expression of growth hormone receptor 1a messenger ribonucleic acid in liver of dairy cows during lactation and after administration of recombinant bovine somatotropin. Journal of Dairy Science 82: 1910-1916.

6. De-Santis C, Jerry DR (2007) Candidate growth genes in finfish where should we be looking? Aquaculture 272: 22-38.

7. Calduch-Giner JA, Mingarro M, Celis S, Boujard D, Perez-Sanchez J (2003) Molecular cloning and characterization of gilthead sea bream (sparusaurata) growth hormone receptor (GHR) assessment of alternative splicing Comparative Biochemistry and Physiology Part B: Biochemistry and Molecular Biology 136: 1-13.
8. Fukada H, Ozaki Y, Pierce AL, Adachi S, Yamauchi K, et al. (2004) Salmon growth hormone receptor: molecular cloning, ligand specificity, and response to fasting. General and Comparative Endocrinology 139: 61-71.

9. Very NM, Kittilson JD, Norbeck LA, Sheridan MA (2005) Isolation, characterization, and distribution of two cDNAs encoding for growth hormone receptor in rainbow trout (Oncorhynchus mykiss). Comparative Biochemistry and Physiology Part B: Biochemistry and Molecular Biology 140: 615-628.

10. Wen-Jing TAO, Long-Jun MA, Rui-Xia RUAN, Ju-Hua YU (2011) SNP loci associated with weight gain on growth hormone receptor genes in Cyprinus carpio var. jian. Journal of Agricultural Biotechnology 20: 301-307.

11. Koenig R, Luddecke P, Haeberle A (1995) Detection of beet necrotic yellow vein virus strains, variants and mixed infections by examining single-strand conformation polymorphisms of immuno-capture Rt-PCR products. Journal of General Virology 76: 2051-2055.

12. Palacio A, Duran-Vila N (1999) Single-strand conformation polymorphism (SSCP) analysis as a tool for viroid characterization. Journal of Virological Methods 77: 27-36.

13. Sambrook J, Russell DW (2001) Molecular cloning: a laboratory manual. (3rdedn), Cold Spring Harbor Laboratory Press, New York.

14. Untergasser A, Nijveen $H$, Rao X, Bisseling T, Geurts R, et al. (2007) Primer 3 plus, an enhanced web interface to primer 3. Nucleic Acids Research 35: W71-W74.

15. Xu Y, Zhu Z, Lo L, Wang C, Lin G, et al. (2006) Characterization of two parvalbumin genes and their association with growth traits in asian seabass (Lates calcarifer). Animal Genetics 37: 266-268.

16. Zhang C, Wang Y, Chen H, Lan X, Lei C (2007) Enhance the efficiency of single-strand conformation polymorphism analysis by short polyacrylamide gel and modified silver staining. Analytical Biochemistry 365: 286-287.

17. Schneider JC, Laarman PW, Howard GJC, Laarman P, Gowing H (2000) Length-weight relationships. Citeseer.

18. Pauly D (1983) Some simple methods for the assessment of tropical fish stocks. Food \& Agriculture Org.

19. Bolger T, Connolly $P$ (1989) The selection of suitable indices for the measurement and analysis of fish condition. Journal of Fish Biology 34: 171182.

20. Lambert Y, Dutil JD (1997) Condition and energy reserves of atlantic cod (Gadus morhua) during the collapse of the northern gulf of St. Lawrence stock. Canadian Journal of Fisheries and Aquatic Sciences 54: 2388-2400.

21. Knaepkens G, Knapen D, Bervoets L, Hanfling B, Verheyen E, et al. (2002) Genetic diversity and condition factor: a significant relationship in Emish but not in German populations of the European bullhead (Cottus gobio L.). Heredity 89: $280-287$

22. Orita M, Iwahana H, Kanazawa H, Hayashi K, Sekiya T (1989) Detection of polymorphisms of human DNA by gel electrophoresis as single-strand conformation polymorphisms. Proceedings of the National Academy of Sciences 86: 2766-2770.

23. Sunnucks $P$, Wilson A, Beheregaray L, Zenger K, French J, et al. (2000) SSCP is not so difficult: the application and utility of single-stranded conformation polymorphism in evolutionary biology and molecular ecology. Molecular Ecology 9: 1699-1710

24. Derdakova M, Beati L, Pet'ko B, Stanko M, Fish D (2003) Genetic variability within Borrelia burgdorferi sensu lato genospecies established by PCR-singlestrand conformation polymorphism analysis of the rrfA-rrlB intergenic spacer in Ixodes ricinus ticks from the Czech Republic. Applied and Environmental Microbiology 69: 509-516.

25. Kjesbu O, Kryvi H, Sundby S, Solemdal P (1992) Buoyancy variations in eggs of Atlantic cod (Gadus morhua L.) in relation to chorion thickness and egg size: theory and observations. Journal of Fish Biology 41: 581-599.

26. Rakitin A, Ferguson MM, Trippel EA (1999) Sperm competition and fertilization success in Atlantic cod (Gadus morhua): Effect of sire size and condition factor on gamete quality. Canadian Journal of Fisheries and Aquatic Sciences 56: 2315-2323.

27. Wilkins N (1967) Starvation of the herring, Clupea harengus L.: Survival and some gross biochemical changes. Comparative biochemistry and Physiology 23: 503-518. 
Citation: Gorji AE, Rahmani H, Miyanji GR (2016) Growth Parameters Evaluation and Identification of Growth Hormone Receptor Gene Polymorphisms in Various Strains of Rainbow Trout Oncorhynchus mykiss. J Aquac Res Development 7: 435. doi:10.4172/2155-9546.1000435

Page 5 of 5

28. Shaki R, Rahmani H, Rahimi G (2011) Comparison of genetic variation in different strains of rainbow trout (Oncorhynchus mykiss) using mitochondrial genome., Sari University of Agricultural Sciences and Natural Resources, Department of Animal Sciences Fisheries. Msc thesis.

29. Lacy RC (1997) Importance of genetic variation to the viability of mammalian populations. Journal of Mammalogy 320-335

30. Shah TH, Balkhi M, Najar A, Asimi OA (2011) Morphometry, length-weight relationship and condition factor of farmed female rainbow trout (Oncorhynchus mykiss walbaum) in Kashmir. Indian Journal of Fisheries 58: 51-56.
31. Rabe FW (1968) Brook trout populations in high lakes. Northwest Science 42 20-28.

32. Cada GF, Loar JM, Sale MJ (1987) Evidence of food limitation of rainbow and brown trout in southern Appalachian soft-water streams. Transactions of the American Fisheries Society 116: 692-702.

33. Ekeng $E$ (1990) Length-weight relationship and diet composition of Ethmalosa fimbriata (Bowdich) (Pisces; Clupeidae) in Cross-River Estuary, Nigeria. Uni. Cross-River, Nig., Ph.D. Thesis.

34. Wootton RS (1992) Fish Ecology. (1stedn), Thomson Litho Limited, Scotland. 